УДК 82.82-3.82-31

DOI: $10.17223 / 24099554 / 6 / 11$

\title{
А.В. Чанцев
}

\section{КРАСОТА ЧЕРЕЗ ГРАНИЦЫ: \\ РЕЦЕПЦИЯ ЭСТЕТИКИ Т. МАННА В ТВОРЧЕСТВЕ Ю. МИСИМЫ}

\begin{abstract}
При всей оригинальности японской культуры в ней всегда было сильно влияние заимствований. Это справедливо даже для такого оригинального писателя, как Ю. Мисима. В данной статье эстетика Ю. Мисимы сравнивается с эстетикой немеикого писателя Т. Манна, большитнство концептов которого он воспринял (тема красоты, смерти, молодости, образы солнца, зеркала). В воздействии и восприятии красоты мы находим прямые заимствования. Ключевые слова: Япония, Германия, межкультурная коммуникация, эстетика, тема красоты, тема смерти, гомосексуальность, Юкио Мисима, Томас Манн.
\end{abstract}

Плохо вы меня знаете, если, восхищаясь эстетической стороной моего творчества, пренебрегаете и нравственными предпосылками, без которых оно немыслимо... Томас Манн. Письмо г-ну Кинбергу. 1937 г.

При всей оригинальности японской культуры в ней всегда было сильно влияние заимствований. Так, кроме буддизма и даосизма из Индии через Китай и Корею, письменности из Китая, в основном из Китая же было заимствовано большинство ставших традиционно японскими искусств. А литература Нового времени сформировалась после Реставрации Мэйдзи под влиянием переводов европейской и во многом русской литературы, театр - под воздействием знакомства с французским театральным искусством и т.д.

Западное влияние было ощутимо и в XX в. - и даже у таких писателей, имеющих имидж сугубо оригинальных и, более того, «западников», как Юкио Мисима.

Для определения генезиса эстетики Мисимы мы сравнили ее с эстетикой немецкого писателя Томаса Манна (1875-1955), автора, который, по признанию самого Мисимы, был не только его самым любимым писателем, но и тем, кто более всего повлиял на формирование его стиля и эстетики в целом. 
В наследии Мисимы, даже среди достаточно многочисленных эссе и автобиографических материалов, не удается отыскать какого-либо отдельного произведения, посвященного разбору собственной рецепции творчества Манна и изложению взглядов по вопросу эстетики Манна. Однако рассыпанные по отдельным его произведениям высказывания, а также данные, приведенные в «Словаре Юкио Мисимы», дают некоторые основания для анализа общего отношения Мисимы к творчеству немецкого писателя, а также для реконструкции воззрений Мисимы на эстетическую систему Томаса Манна.

Известно, что в разговоре с писателем и театральным деятелем Фунабаси Сэйити Мисима признался, что «считает Томаса Манна лучшим писателем в мире». В книге «История моих странствий» («Ватакуси-но хэнрэки-дзидай», 1957) Мисима пишет о том, что начал читать Манна в 1951 г., в возрасте 26 лет, и с тех пор постоянно возвращается к нему и перечитывает: «Произведения Манна с тех пор стали для меня идеальной литературой» [1. С. 63]. Там же он замечает, что в произведениях Манна «в идеальной гармонии пребывают художественная ценность и вульгарность» [1. С. 64]. Кроме того, Мисима указывает, что привлекало и отталкивало его в Манне: «Его тевтонская непреклонность и ненужная дотошность далеки от моего собственного характера. Но меня восхитили драматичность его творчества, уникальный характер трагедии в германской литературе и сочетание высочайшего писательского мастерства и чувство дискриминации, граничащее с надменностью» [1. С. 54-55]. В своей книге «Попытка самореконструкции» («Дзико-кайдзо-но кокороми», 1957), посвященной проблемам стиля и разбору творчества Мори Огаи, Мисима говорит о том, что «Золотой храм» был написан под влиянием Мори Огаи и Томаса Манна, и там же находим следующее любопытное высказывание: «<...> если обратиться к классификации Манна, то преклонный возраст проходит под знаком мужественности, молодость - под знаком женственности, дух является мужественным, а телесность - женственной. В моем стиле я следую тем же путем, что и многие юноши» [2. С. 15]. В эссе «Бокс и литература» («Бокусингу-то сёсэцу», 1955), посвященном его опытам в боксе, Мисима утверждает, что под влиянием любви к творчеству Манна изменился не только его взгляд на людей, но и на искусство.

У Мисимы можно также найти некоторые высказывания о конкретных произведениях Манна. Так, в статье «О красоте» («Би-ни цуйтэ») Мисима пишет о том, что если рассматривать «Смерть в Ве- 
неции» «с точки зрения чистого искусства», объектом критики Манна «является красота, влекущая к смерти» (цит. по: [3. С. 401]). Название новеллы Манна несколько раз встречается в книге Мисимы «Тело и костюм» («Ратай-то исё», 1959). В самой же новелле Манна мы можем встретить архетипичный для творчества Мисимы образ Святого Себастьяна, а также греческую символику и упоминание имен Федра и Сократа, что отсылает нас к «Запретным цветам», «Исповеди маски» и другим произведениям Мисимы. Подробнее об использовании этих образов у Манна и Мисимы мы скажем далее. Следует отметить, что причины использования одних и тех же исторических персонажей и сходства символики у Манна и Мисимы, по замечанию японских критиков, неясны: напрашивается вывод о том, что образ Святого Себастьяна был заимствован Мисимой у Манна, но прямых тому подтверждений, например в виде высказываний Мисимы по этому поводу, до сих пор не обнаружено [3. С. 400].

Сравнение их эстетик дает все основания полагать, что Мисима плодотворно воспринял многие идеи Манна, использовал их в своем творчестве, переосмыслял их. Это касается таких генеральных для эстетики Мисимы концептов, как тема смерти, телесности, болезни, молодости, гомоэротизма, а также символика прекрасного. У Манна же Мисима воспринял и греческую эстетику, а также образ Святого Себастьяна. Это также сопутствующая образам прекрасного символика - солнце, сияние. Тема красоты у Манна сопровождается теми же сопутствующими мотивами, что и у Мисимы, а именно темами нарциссизма, зеркала, физически уродливых персонажей, жаждущих восполнить недостаток собственный красоты за счет приобщения к красоте универсальной, темой двойников и шире - амбивалентности и антиномичности красоты, темой невыразимости красоты традиционными творческими механизмами (в «Смерти в Венеции» и «Докторе Фаустусе» у Манна и в «Запретных цветах» Мисимы). У Манна удается обнаружить даже такие специфические темы, характерные и для творчества Мисимы, как аскетичность красоты (у Манна это знак праведников вроде Иосифа, у Мисимы - самураев и молодых революционеров) и даже темы красоты обнаженных внутренностей (в «Волшебной горе»).

Главным же, что воспринял Мисима у Манна, было само восприятие красоты: ее характеристики (демоничность, внеморальность, порочность), варианты реакции на нее индивида (зависимость от красоты, тираническая власть над жертвами ее чар, тщетные по- 
пытки человека наладить с красотой контакт, попытки освободиться от нее, желание отомстить, в конечном итоге убить красоту) и способы реализации (трансцендентность и воплощение в каком-либо конкретном объекте в этом мире). В реализации этих идей Мисима наследует Манну, как и в главном - в идее соотношения эстетики и этики, преодоления примата красоты над этикой, поиска их гармоничного сосуществования, а также вписывания в мир гомогенной красоты идеи Бога.

Союз духа и красоты разрешил бы самую главную проблему в эстетической системе Манна (да и Мисимы), это было бы универсальным решением. Если бы это воплотилось в жизнь, то результатом была бы не только праведность Иосифа, но и «вливание» в этот мир гармонии («снова пустить в мир»), чуть ли не воплощение рая на земле. Решение это, как сказано, возможно только в человеке. Это понимает и сам человек - Иосиф обеспокоен той же проблемой: «Для Иосифа этой пленительной идеей было сожитие тела и духа, красоты и мудрости и взаимоусиливающее сознание того и другого. <...> Иосиф не верил этому; но когда он хотел ощутить свое бытие и тайно ему порадоваться, он вспоминал о кровавом смешении земного с божественным, чувствовал, к странному своему счастью, что и сам он состоит из этого вещества, и, улыбаясь, думал, что сознание тела и красоты должно быть улучшено и усилено сознанием духа, и наоборот» [4. С. 333]. Но даже в образе праведного Иосифа дух и красоту полностью объединить не удалось, единение было почти достигнуто, но в абсолютной своей форме так и не реализовалось. Поэтому полное и гармоничное слияние красоты и духа невозможно - возможно только «смешение», причем «кровавое», т.е. трагическое.

Невозможно подобное слияние, как представляется, по двум причинам. Во-первых, один из двух компонентов - красота - абсолютно во всех случаях, будь то праведный Иосиф или уж совсем безгрешная Рахиль, содержит хоть какой-нибудь элемент порочности, болезни, демонизма. Во-вторых, само слияние возможно только в человеке, а человек также порочен. Вторая причина может быть выведена из первой (человек порочен, ибо красив) или, на более высоком уровне обобщения, из фундаментальных свойств человека: человек не невинен после грехопадения, грехопадение же произошло из-за наделения духа телесностью (т.е. по сути первой попытки слияния духа и красоты), а телесность есть сосредоточие красоты, так как красота базируется в теле (Иосиф думает именно о слиянии 
«тела» и «духа»). То, что сотворение человека Богом можно трактовать и как первую попытку слияния духа и красоты, находит подтверждение в мысли о взаимовлиянии Бога и человека: «Для чего же еще, спрашивается, нужен союз? Наказ бога человеку «Будь свят, как я!» уже предполагает освящение бога в человеке и означает собственно: «Пусть я свят в тебе, а потом будь и сам свят!» Другими словами, очищение бога от мрачного коварства и его освящение очищает и освящает человека, в котором, по настоятельному желанию бога, происходит этот процесс» [5. С. 263-264].

Таким образом, тотальная (и оттого трагическая) невозможность слияния духа и красоты становится проблемой не только антропологической, но и проблемой мира сакрального, т.е. проблемой воистину онтологической - из-за несоединимости духа и красоты труднее становится слияние человека и Бога, их взаимное улучшение друг в друге. Здесь стоит заметить, что все проблемы соотношения телесности, духовности, красоты, замысла Бога о человеке и т.д. находят достаточно простое объяснение в сфере традиционной христианской религиозности. Богу ничего не нужно было соединять, ни красоту с телесностью, ни себя с человеком - все было едино изначально. Единство было нарушено грехопадением человека, в результате которого он отпал от Бога, а внутри у него сделались автономными интеллект, красота, эмоции, воля и т.д., причем и последние также утратили цельность, началась внутренняя борьба интеллекта, эмоции и прочего. Интуитивно человек ощущает, что такое состояние ненормально, смутно припоминает, что раньше было как-то иначе (лучше), но способ возвращения к этому единству представляет для него большой вопрос. В христианстве есть на него четкий и прямой ответ: только через Христа, который есть Путь. Вопросы же соотношения телесности и духовности, эстетичности и этичности и т.д. вторичны, однако именно они для героев Манна и Мисимы становятся первичными. Происходит это, как представляется, потому, что, во-первых, ни Манн, ни тем более Мисима не разделяли традиционных христианских взглядов, а лишь вели свой диалог с христианством; во-вторых, потому что и Манн и Мисима в полной мере являются мыслителями века XX, века дисгармонического существования человека ${ }^{1}$, и такие вторичные для христианства проблемы, как авто-

${ }^{1}$ Т.С. Элиот в эссе «Поэты-метафизики» (1924) ввел специальное понятие «распад цельности мировосприятия» (dissociation of sensibility) как определение нарушенной духовно-чувственной цельности бытия. 
номная красота и воля человека, а также трагическое расщепления этики и эстетики становятся для них первостепенными, привлекают к себе их творческие интенции.

Эксперимент по созданию персонажа, в котором бы гармонично сочеталась красота и дух, поставленный Манном в «Иосифе и его братьях», завершился не совсем удачно. А такие поздние произведения Манна, как «Доктор Фаустус» и «Избранник», дают основания говорить об окончательной неудаче в поиске возможности гармонично объединить красоту и дух, эстетику и этику.

Особенно символична в этом плане повесть 1950 г. «Избранник», где герои после многочисленных испытаний, отказа от физической красоты, умаления плоти и за счет истовой религиозной деятельности вроде бы приобщились праведной жизни. Сам семантический анализ финала этой повести говорит о том, что красота отнюдь не сдалась духу: слова «прелесть» и «соблазн», близкие к религиозному термину «искус», а также фраза о том, что «благородство тела» (т.е. его красота) сохранилось «вопреки христианским покаяниям души», знаменует то, что красота с ее греховностью может быть лишь отчасти подавлена, «нейтрализована» религиозной этикой, но полностью быть побеждена ею не может. Красота слишком сильна, слишком сильны сопутствующие ей качества, такие, например, как болезнь. Конфликт между красотой и духом, разрешенный, казалось бы, в «Иосифе и его братьях», возникает здесь снова - и опять не разрешен до конца.

Сочетание духа и красоты, эстетики и этики оказалось в принципе возможно (в образе Иосифа это осуществляется максимально), но не действенно, так как красота все равно оказывается более могущественной силой. Это, безусловно, не такой провал всех эстетических исканий, как в эстетике Мисимы под конец его творчества, когда «красота оказалась фантомом», а сад, символизирующий мироздание, оказался пуст. Однако самая крупная задача, которую ставил перед собой Манн в создаваемой им эстетической картине мира, все же не решена. Что и оставляет возможность Мисиме впоследствии продолжить свои изыскания примерно с того места, где их оставил Манн, и, заметим, с тем же результатом.

При этом стоит говорить не о заимствовании тем, а об их переосмыслении у Мисимы. Какие-то темы Мисима не воспринял (мотив саморефлексии красоты - у Мисимы красота лишена со- 
знания, мотив принесения красоты в жертву - у Мисимы объект красоты можно убить, но это не есть жертвоприношение), какието развил (тема трансценденции и ритуалов приобщения к трансцендентальной красоте), какие-то нюансировал (у Мисимы есть строгая иерархия, стратификация субъектов прекрасного). Нельзя забывать и национальную специфику. Так, пытаясь привнести в свою эстетическую систему этический элемент, Манн апеллировал к христианским идеям, а Мисима использовал элементы синтоизма и кодекса бусидо.

То, что в конечном итоге оба писателя приходят к одному и тому же выводу - мир красоты не терпит присутствия никакого этического идеала, а мир без этики, с одной красотой, чреват моральным разложением и гибелью для попавшего в него индивида - более всего сближает, как нам кажется, их поэтику.

\section{Литература}

1. Мисима Ю. Ватакуси-но хэнрэки-дзидай (История моих странствий). Токио: Коданся, 1982. Перевод мой.

2. Мисима Ю. Дзико-кайдзо-но кокороми («Попытка самореконструкции»). Токио: Бунгакукай, 1957. Перевод мой.

3. 長谷川泉、野口武彦編. 三島由紀夫辞典。東京明治劃完. 1976. Хасэгава И., Такэико Н. Мисима Юкио дзитэн. Токио: Мэйдзи-сёин, 1976.

4. Манн Т. Иосиф и его братья: в 2 т. М.: Правда, 1991. Т. 1.

5. Манн Т. Иосиф и его братья: в 2 т. М.: Правда, 1991. Т. 2.

Chantsev, Alexander V. Independent researcher (Moscow, Russian Federation). E-mail: semigoro@yandex.ru

BEAUTY BEYOND FRONTIERS: RECEPTION OF T. MANN'S AESTHETICS BY Y. MISHIMA

Imagologiya i komparativistika - Imagology and Comparative Studies, 2016, 2(6), pp. 155-162. DOI: 10.17223/24099554/6/11

Keywords: Japan, Germany, intercultural communication, aesthetics, theme of beauty, theme of death, homosexuality, Yukio Mishima, Thomas Mann.

Though original, Japanese culture has always been influenced by those of other countries. It is also true for such an independent writer as Yukio Mishima. In the development of his aesthetics system, Mishima adopted most of the aesthetic concepts of his favorite writer T. Mann: themes of beauty, death, youth, the images of sun and mirror. The reception of beauty by Mishima's characters was also strongly influenced by Mann. The development of Mann's aesthetics is also of deep interest, as it contains the traces of Christian aesthetic system, which, in combination with such concepts as death and homosexuality, makes this system almost unique. Mishima was the one who accepted and incorporated this complicated aesthetics system in his creativity. 


\section{References}

1. Mishima, Yu. (1982) Vatakusi-no khenreki-dziday [The history of my wandering]. Tokyo: Kodansha. Translated from Japanese by A. Chantsev.

2. Mishima, Yu. (1957) Dziko-kaydzo-no kokoromi [Trying reconstruction]. Tokyo: Bungakukay. Translated from Japanese by A. Chantsev.

3. Hasegawa, I. \& Takehiko N. (eds) (1976) Misima Yukio dziten [A Dictionary of Mishima Yukio]. Tokyo: Meydzi-sein. Translated from Japanese by A. Chantsev.

4. Mann, T. (1991a) Iosif i ego brat'ya: V 2 t. [Joseph and His Brothers: In 2 vols]. Vol. 1. Moscow: Pravda.

5. Mann, T. (1991b) Iosif i ego brat'ya: V 2 t. [Joseph and His Brothers: In 2 vols]. Vol. 2. Moscow: Pravda. 